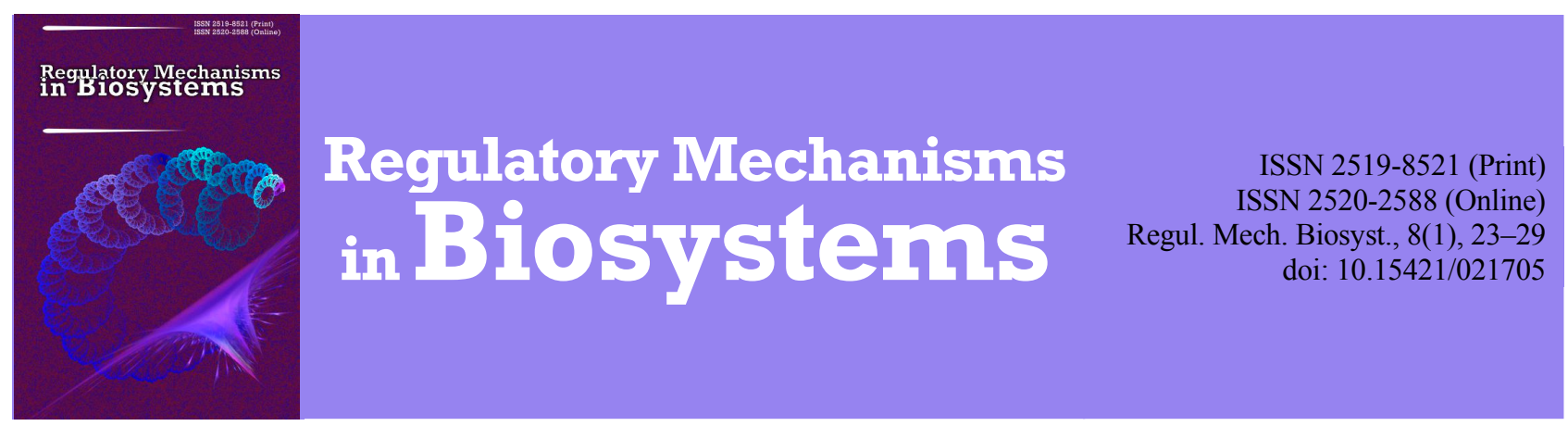

\title{
Obesity: The role of desynchronosis and genetic factors in mechanisms of its development
}

\author{
M. O. Ryznychuk*, V. P. Pishak** \\ *Bukovinian State Medical University, Chernivtsi, Ukraine \\ **National Academy of Pedagogical Sciences, Kyiv, Ukraine
}

Article info

Received 16.12.2016

Received in revised form 29.01.2017

Accepted 02.02.2017

Bucovinian State Medical University, Teatralnaya Sq., 2, Chernivtsi, 58001, Ukraine Tel.: + 38-050-192-09-53 E-mail: rysnichuk@mail.ru

National Academy

of Pedagogical Sciences

of Ukraine, Sichovykh Streltsiv

Str., 52-A, Kyiv, 04053, Ukraine

Tel.: +38-095-884-76-58

E-mail:pishakv@mail.ru
Ryznychuk, M. O., \& Pishak, V. P. (2017). Obesity: The role of desynchronosis and genetic factors in mechanisms of its development. Regulatory Mechanisms in Biosystems, 8(1), 23-29. doi: 10.15421/021705

The article highlights the role of desynchronosis and certain genetic factors in the development of obesity. Some pathogenetic links of obesity and the influence of melatonin on them are analyzed. Desynchronosis is one of the causes of obesity as a result of dysregulatory changes in the chronoperiodic system - between suprachiasmatic nuclei of the hypothalamus and secretory activity of the pineal gland. In obesity there are some changes in circadian patterns of important physiological parameters. These include acrophases of blood pressure; rhythm of hormone secretion, including insulin; electrolytes; sleep-wake cycle displaced for a period of a day, which is a deviation from the normal course. Phase discrepancies of established circadian oscillations of physiological processes arise. Preconditions of fat metabolism imbalance, particularly visfatin, apelin and vaspin - components of atherosclerotic lesions, gradually emerge. There is abundant evidence for close relationships between metabolism and circadian mechanisms. It is proved, that there is a strong direct impact of endogenous circadian rhythms on the metabolic pathways that do not depend on food intake or sleep. A potential low molecular weight of biomarkers of human circadian phases has been identified. A number of key metabolic enzymes in tissues such as the liver, adipose tissue or the pancreas are chronodependent. Desynchronosis phenomena caused by genetic or environmental factors can lead to serious metabolic disorders, including obesity, insulin resistance and metabolic syndrome. Genesis of pineal removal-induced insulin resistance and reduced glucose tolerance in cells is related to the consequences of melatonin absence, which leads to abnormalities in insulin signaling pathways and reduced GLUT4 gene expression and protein content. Insulin-sensitive tissues (white and brown adipose tissue, skeletal and heart muscles) after pineal removal are characterized by a significant reduction of GLUT4 mRNA and the content of microsomal and membrane proteins, which are compensated during treatment by melatonin. Functional synergy exists between melatonin and insulin. Melatonin is able through the membrane receptors MT1 to cause rapid tyrosine phosphorylation, activate tyrosine kinase of beta subunits of insulin receptors and mobilize several intracellular stages of insulin-signaling pathway transduction. Thus, the protective effect of melatonin in cases of disturbance to the carbohydrate metabolism is manifested in the formation of circadian periodicity by modulating the expression of time genes.

Keywords: melatonin circadian mechanisms; gene; epiphysis

\section{Ожиріння: роль десинхронозу та генетичних чинників у механізмах його розвитку}

\author{
М. О. Ризничук*, В. П. Пішак** \\ *Буковинський державний медичний університет, Чернівиі, Украйна \\ **Національна академія педагогічних наук, Київ, Украӥна
}

Висвітлено роль десинхронозу та генетичних чинників у розвитку ожиріння. Проаналізовано окремі патогенетичні ланки розвитку ожиріння та вплив на них мелатоніну. Десинхроноз - одна з причин ожиріння, як наслідок дизрегуляторних зрушень у хроноперіодичній системі - між супрахіазматичними ядрами гіпоталамуса та секреторною активністю шишкоподібної залози. Існує багато доказів того, що між метаболізмом і циркадіанним механізмом існують тісні взаємозв'язки. Доведено сильний прямий вплив ендогенних циркадіанних ритмів на метаболічні шляхи, які не залежать ні від прийому їжі, ні від сну. Ідентифіковано потенційні низькомолекулярні біомаркери циркадіанних фаз людини. Низка ключових ферментів метаболізму в таких тканинах як печінка, жирова або тканина підшлункової залози - хронозалежні. Явища десинхронозу, спричинені генетичними чи зовнішніми чинниками, можуть спричинити серйозні метаболічні порушення: ожиріння, резистентність до інсуліну та метаболічний синдром. Генезис пінеалектоміє-індукованої резистентності до інсуліну та зниження толерантності до глюкози в клітинах пов'язаний із наслідками відсутності мелатоніну, що викликає розвиток порушень інсулінового сигнального шляху та 
зниження експресії генів GLUT4 та вмісту білка. Інсулін-чутливі тканини (біла та бура жирові тканини, скелетні та серцеві м’язи) при пінеалектомії характеризуються суттєвішим зниженням мРНК GLUT4, вмістом мікросомальних і мембранних білків, які компенсуються під час проведення терапії мелатоніном. Існує функціональний синергізм між мелатоніном та інсуліном. Мелатонін здатний через мембранні рецептори МТ1 викликати швидке тирозин-фосфорилювання та активувати тирозинкіназу бета-субодиниці рецептора інсуліну та мобілізацію декількох внутрішньоклітинних етапів трансдукції інсулін-сигнального шляху. Захисна дія мелатоніну у разі порушення вуглеводного обміну виявляється у формуванні циркадіанного періодизму шляхом модуляції експресії часових генів.

Ключові слова: мелатонін; циркадіанний ритм; гени; епіфіз

\section{Вплив порушень циркадіанного ритму на розвиток ожиріння}

Поширеність порушень сну нині у людській популяції сягає 80-95\%. Щорічно нестачу сну відчувають від 1/3 до $1 / 2$ населення, а в 10-15\% людей безсоння - клінічно значуща проблема, яка різко знижує якість життя. Ожиріння межує 3 пандемією XXI століття, становить серйозну медико-соціальну проблему. Це основна причина інвалідизації та смертності серед осіб середнього та літнього віку в усьому світі (Hotamisligil et al., 1993; Knutson and Van Cauter, 2008). Серед причин можна виділити чинники як загального характеру (екологічні), так і індивідуальні (генетичні) особливості. Ожирінню сприяє порушення режиму харчування, надмірне вживання їжі, що порушує енергетичну рівновагу, неконтрольоване збагачення їжі жирами та вуглеводами, збіднення білками, вітамінами, макрота мікроелементами спричиняє дисбаланс харчового раціону, а також нездоровий спосіб життя людини, недостатня фізична активність, стреси тощо (Hasler et al., 2004).

Це неповний перелік чинників, які зумовлюють низку біохімічних та фізіологічних процесів в організмі, зокрема, заміщення вуглеводного обміну жировим, зростання маси тіла внаслідок підвищення рівня ліпопротеїдів низької густини, гіперстимуляція $\beta$-клітин підшлункової залози, підвищення секреції інсуліну, розростання жирової тканини зі збільшенням об'єму вісцерального жиру на животі та у верхній половині тулуба (Van Cauter and Knutson, 2008).

Відносно недавно з'ясовано, що одна з причин ожиріння десинхроноз, як наслідок дизрегуляторних зрушень у хроноперіодичній системі - між супрахіазматичними ядрами гіпоталамуса та секреторною активністю шишкоподібної залози (Rapoport et al., 2013).

Упродовж останнього десятиліття проведено велику кількість досліджень щодо залежності ожиріння від циркадіанного ритму, які виявили чітку закономірність: навіть невеликі за тривалістю періоди депривації сну спричиняють підвищення вісцерального ожиріння, внаслідок зниження «пластичності» метаболічних процесів і розвитку резистентності до інсуліну (Knutson et al., 2007; Syromjatnikova et al., 2010).

Проведення кореляційного аналізу (Lundina et al., 2014) виявило пряму залежність тяжкості порушення циркадіанного ритму від індексу маси тіла в дітей $з$ ожирінням $(\mathrm{r}=0,63, \mathrm{P}=$ $0,003)$ : тобто, чим більший індекс маси тіла у дитини, тим більш виражені порушення циркадіанного ритму. Патологічні типи циркадіанного ритму достовірно частіше траплялися в дітей з ожирінням ( $66 \%$ проти $14 \%, \mathrm{P}<0,05)$.

Центральний водій ритму циркадіанної системи - первинне джерело інформації про ритмічність для фізіологічних процесів, розташований у супрахіазматичних ядрах (СХЯ) гіпоталамуса. Світловий сигнал синхронізує водія ритму із зовнішнім циклом «світло - темрява» через прямий ретиногіпоталамічний тракт від сітківки до СХЯ. Останні також отримують опосередковано несвітлову інформацію, наприклад, із ядер шва. Складні нейрональні шляхи з'єднують СХЯ з шишкоподібною залозою, в якій здійснюється синтез мелатоніну відповідно до циркадіанних коливань освітленості довкілля. Центральні мелатонінові рецептори (МТ1 та МТ2) розташовані переважно в СХЯ, в яких мелатонін діє за принципом зворотного негативного зв'язку.

Дослідженнями (Nishida, 2005; Peschke, 2008; Antunes et al., 2010) показано, що уведення витяжки 3 шишкоподібної залози викликало розвиток гіпоглікемії, підвищення толерантності до глюкози, а також до стимуляції глікогенезу у печінці та м'язах у відповідь на ін'єкцію глюкози. Навпаки, пінеалектомія спричиняє зменшення толерантності до глюкози та гальмує глікогенез у печінці та м'язах. Метаболічні порушення, викликані відсутністю мелатоніну у пінеалектомованих тварин, охарактеризовані як діабетогенний синдром, який включає порушення толерантності до глюкози та резистентність периферичної (печінка, жирова тканина та скелетні м'язи) та центральної ланок (гіпоталамус) до інсуліну (Reiter et al., 1980; Balagopal et al., 2007; Laposky et al., 2008). Така клініка може нівелюватися уведенням мелатоніну або обмеженням годування (Hairston et al., 2010), але не заняття фізичною культурою (Brondel et al., 2010). Резистентність до інсуліну, порушення толерантності до глюкози, а також деякі зміни інших метаболічних параметрів можна виявити за фізіологічних або патофізіологічних станів, пов'язаних зі зниженням рівня мелатоніну у крові, наприклад, старіння, діабет, позмінна робота та високий рівень освітленості вночі (Everson, 2004; Picchi et al., 2006; Broussard et al., 2010). Адекватна терапія мелатоніном полегшує більшість зазначених патологічних метаболічних змін. Аналогічний метаболічний синдром спостерігається у тварин із блокадою МТ1рецепторів (Mulder et al., 2009).

Існує багато доказів того, що між метаболізмом і циркадіанним механізмом існують тісні взаємозв'язки. Сильний прямий вплив ендогенних циркадіанних ритмів на метаболічні шляхи, які не залежать ні від прийому їжі, ні від сну (Dallmann et al., 2012). Ідентифіковано потенційні низькомолекулярні біомаркери циркадіанних фаз людини. Низка ключових ферментів метаболізму у таких тканинах як печінка, жирова або тканина підшлункової залози - хронозалежні (Knutson et al., 2008). Явища десинхронозу, спричинені генетичними або зовнішніми чинниками, можуть спричинити серйозні метаболічні порушення: ожиріння, резистентність до інсуліну та метаболічний синдром (Laposky et al., 2008; Kovac et al., 2009; Bass and Takahashi, 2010).

Провідна роль у патогенезі сімейних та більшості спорадичних випадків ожиріння належить спадковим чинникам, які визначають генетичну схильність до захворювання. Генетична схильність до метаболічних відхилень, що спричиняють ожиріння, розглядається як модифікований чинник ризику. Складність генетичного аналізу такого гетерогенного, багатофакторного захворювання як ожиріння полягає у великій кількості потенційних генів-кандидатів, здатних брати участь у формуванні генної мережі спадкової схильності до ожиріння. Участь поліморфізмів генів, схильних до формування ризику захворювання та його клінічних проявів, перебуває на початкових стадіях вивчення. Залишається нерозв'язаним питання кореляції між порушенням ліпідного обміну та наявністю поліморфних пошкоджувальних алелів у генах, продукти яких залучаються до метаболізму ліпідів і ліпопротеїдів (Klimov and Nikulcheva, 1999; Baranov et al., 2000).

Із кінця XX століття в усьому світі число осіб з ожирінням більше ніж подвоїлося (International Obesity Task Force, 2010). Це може бути зумовлено як зовнішніми чинниками (неправильним способом життя, у тому числі незбалансованим харчуванням), так і генетичними порушеннями. Чинники ризику середовища, пов'язані зі зміною характеру харчування та фізичною активністю, можуть реалізуватися тільки на тлі генетичних чинників (McCarthy, 2010). 


\section{Генетична складова в розвитку ожиріння}

Підтверджено роль генетичної схильності розвитку ожиріння. Імовірність надлишкової маси тіла за наявності ожиріння у батьків становить 70-80\%, хоча в загальній популяції цей показник - близько $30 \%$. Відкрито багато генів кандидатів: гени, що кодують утворення $\beta 3$ - і $\beta 2$-адренорецепторів, ген ліпопротеїнліпази, гени рецептора 3,4 типу меланоцитостимулювального гормону (MC3-R, MC4-R), agouti, PRAR $\gamma$, FTO, UCP2, fat-ген тощо. Нині визначено близько 1000 генів, асоційованих 3 ожирінням. Усі вони вказані в міжнародній базі даних Human Genome Epidemiologi Network (HuGeNet). $€$ форми ожиріння, зумовлені дефектом єдиного гена. Однак необхідно зазначити, що на їх частку припадає не більше $5 \%$ від усіх випадків ожиріння. У більшості гени лише зумовлюють схильність до надмірного накопичення жирової тканини за дії різних зовнішніх чинників навколишнього середовища. Причини надлишкової маси тіла полягають перш за все в особливостях стилю життя та харчової поведінки, а також у недостатній щоденній фізичній активності (Borodina, 2016).

Під час обстеження дітей і дорослих у різних популяціях виявлено понад 100 генетичних поліморфізмів, пов'язаних 3 ожирінням (Carlos et al., 2013). Виявлено асоціацію поліморфізму rs9939609 гена FTO зі збільшенням індексу маси тіла (IMT), відсутністю відчуття насичення їжею та підвищенням ризику розвитку ожиріння (Mitchell et al., 2010). Найбільш вивчений у цілому ряді етнічних груп на даний час поліморфний маркер гена KCNJ11 rs5219, в якому відбувається заміна цитозину на тимін у позиції 67, яка веде до заміни глутамінової кислоти у позиції 23 амінокислотної послідовності білка на лізин (Qiu et al., 2014). Показана асоціація цього поліморфізму 3 ризиком розвитку цукрового діабету (ЦД) ІІ типу в європейців, в індоєвропейській етнічній групі, в американців європейського походження, японців та китайців (Cejkova et al., 2007). Установлено зв'язок поліморфізму rs5219 KCNJ11 гена 3 ризиком розвитку ЦД II типу у жителів арабських держав, а у жителів Японії та Південної Кореї - також зв'язок із ризиком розвитку артеріальної гіпертензії (Koo et al., 2007; Sakamoto et al., 2007). У турецькій популяції виявлено статистично значущий зв'язок алеля T зі зниженням рівня секреції інсуліну (Gonen et al., 2012).

Важливу роль у регуляції величини маси жирової тканини відіграє також поліморфізм гена $\beta 3$-адренорецепторів (ADRB3). Мутація в кодоні 64 гена ADRB3 зумовлює заміну триптофану на аргінін (Trp64Arg) у білку рецептора й асоціюється 3 надлишковою вагою. Результати досліджень із включенням 11 тис. людей свідчать про те, що мутація Trp64Arg гена ADRB3 поширена в декількох етнічних групах, пов'язана 3 вісцеральним ожирінням, резистентністю до інсуліну та раннім розвитком ЦД II типу (De Luis et al., 2007).

Значна кількість досліджень присвячена генам, пов'язаним 3 енерговитратами, а саме тим, що кодують мітохондріальні роз'єднувальні білки (UCP) та являють собою родину мембранних білків, носіїв аніонів, розташованих на внутрішній мембрані мітохондрій (Dalgaard, 2011). Найбільше вивчено поліморфізм rs659366 гена, який роз'єднує білок 2 (UCP2) - ключового регулятора енергетичного балансу. Він наявний на внутрішній мембрані мітохондрій, опосередковує вихід протонів через внутрішню мембрану шляхом роз'єднання окиснення АТФ, таким чином, зменшується синтез АТФ у мітохондріальному дихальному ланцюгу. Ефектом UCP2 може бути пригнічення стимульованої глюкозою секреції інсуліну.

Метааналіз поліморфізму rs659366 гена UCP2, із загальною кількістю обстежених 7390 (контрольна група) і 9890 (пацієнти $з$ ожирінням), показав статистично значущу асоціацію 3 ожирінням у вихідців з Свропи, на відміну від вихідців з Азії, де зв'язку з ожирінням не виявлено (Qian et al., 2013).

Патогенез ожиріння пов'язаний із порушеннями обмінних процесів, які можуть викликати інсулінорезистентність, пору- шеної толерантності до глюкози та розвитку ЦД II типу. Секрецію інсуліну $\beta$-клітинами підшлункової залози регулює АТФ-залежний калієвий канал за допомогою впливу на метаболізм глюкози на рівні мембран клітин.

\section{Роль мелатоніну у вуглеводному та жировому обмінах}

При ожирінні виникають певні зміни циркадіанної структури важливих фізіологічних показників. Акрофази артеріального тиску, ритмів секреції гормонів, зокрема інсуліну, електролітів, циклу «сон - бадьорість» зміщаються на період доби, не властивий нормальному перебігу (Hayes et al., 2011). Виникають фазові неузгодження усталених циркадіанних коливань фізіологічних процесів. Поступово формуються передумови дисбалансу обміну жирів, зокрема, вісфатину, апеліну, васпину - компонентів атеросклеротичних пошкоджень (Hairston et al., 2010; Kessler et al., 2010; Rosa et al., 2010).

Первинна ланка дезадаптаційних зрушень торкається печінки та підшлункової залози. У тканині печінки внаслідок активного адипоцитарного ліполізу збільшується рівень холестерину та тригліцеридів, а вміст вільних жирних кислот підвищується у 20-30 разів понад норму. Під час блокади інсулінових рецепторів виникає інсулінорезистентність, поглиблюється порушення транспорту глюкози в гепатоцитах, зростає надмірне засвоєння моновуглеводу гладеньком'язовими клітинами та адипоцитами (Biggi et al., 2008; Rios-Lugo et al., 2010; Rosa et al., 2010).

Стрептозотоциновий діабет супроводжується гіперглікемією, зниженням толерантності до вуглеводного навантаження, гальмуванням активності глюкокінази та глюкозо-6-фосфатдегідрогенази у тканині печінки та інтенсивності антиоксидантного статусу. Попереднє уведення мелатоніну (5 мг/кг, упродовж 15 діб) запобігає зазначеним змінам (Akmali et al., 2010). На антидіабетичному ефекті мелатоніну наголошують S. Nishida (2005), E. Pesche (2008), I. Bahr et al. (2011).

У щурів лінії Goto-Kakizaki зі стрептозотоциновим діабетом спостерігалася гіперінсулінемія та гіперліпідемія, зниження концентрації глюкагону й активності тирозинкінази рецептора інсуліну. У цій ситуації також установлено чіткий антидіабетичний ефект мелатоніну (Nishida, 2005; Janke et al., 2006, Bahr et al., 2011). В епіфізектомованих щурів спостерігається зниження щільності острівців Лангерганса та руйнування їх клітинних елементів (Picinato et al., 2008, Kasradze et al., 2010). Додавання мелатоніну в інкубаційне середовище гепатоцитів, отриманих від мишей із діабетом, збільшувало в них синтез глікогену, причому цей ефект усувався антагоністом мелатоніну лузиндолом (Shieh et al., 2009). Цікаво, що мелатонін полегшував приживлення трансплантата острівців Лангерганса в мишей із діабетом (Lin et al., 2009). Результати поки нечисленних досліджень на людях у принципі збігаються з експериментальними даними та підтверджують захисні антидіабетичні властивості мелатоніну.

Низкою праць Э. Б. Арушаняна и соавт. $(2011,2012)$ чітко обгрунтовано можливість участі шишкоподібної залози, іiі гормону мелатоніну в регуляції енергетичного метаболізму. Мелатонін помітно пригнічував секрецію інсуліну $\beta$-клітинами підшлункової залози in vitro, посилював експресію та секрецію глюкагону $\alpha$-клітинами (Guzik et al., 2006, Donga et al., 2010). У щурів, яким згодовували їжу, збагачену жирами, підвищувалася концентрація в крові інсуліну, глюкози, тригліцеридів і адипонектину. Одночасне додавання до питної води мелатоніну (25 мкг/мл упродовж 11 тижнів) нормалізувало зазначені зрушення (Peschke et al., 2008; Scheer et al., 2009).

Виявлено два типи рецепторів для зв'язування мелатоніну в клітині - MT1 (ген MTNR1A) і MT2 рецептори (ген MTNR1B) на плазматичній мембрані, та рецептори на ядерній мембрані (NR1F1 i NR1F2 або ROR / RZR). Ці ж рецептори виявлені також на $\beta$-клітинах підшлункової залози (Mulder et al., 2009). Рецептори (MT1 і МТ2) також розпізнають інсулін. 
Зв'язування мелатоніну з МТ1-рецепторами ініціює два сигнальні шляхи. Стимуляція першого шляху викликає підвищення активності фосфатидилінозитол-3-кінази (РІ3K), фосфоліпази А2 і C, AKT/PKB- i ERK1/2-кінази, білка STAT3 (Picinato et al., 2008), стимулювання другого шляху спричинює пригнічення аденілат- і гуанілатциклази (Ha et al., 2006; Molchanov, 2012). Через це кількість цАМФ і цГМФ у клітині починає зменшуватися (Ha et al., 2006). Обидва шляхи запускаються одночасно, проте за короткої стимуляції, особливо в ранкові години, активніший перший шлях, а за тривалої стимуляції, особливо у вечірні години або за великої дози екзогенного мелатоніну, активується другий шлях (Bespjatyh et al., 2009). Через МТ2-рецептори здійснюється циркадіанна корекція секреції інсуліну $\beta$-клітинами та глюкагону $\alpha$-клітинами (Pesch$\mathrm{ke}, 2008)$. За тривалої дії мелатоніну на клітини інсуліноми в $\beta$-клітинах активуються синтез і екстерналізація МТ2-рецепторів, внаслідок чого зменшується кількість інсуліну, що секретується, оскільки ці рецептори пов'язані винятково $з$ аденілатциклазним шляхом (Picinato et al., 2008; Mulder et al., 2009; Molchanov, 2012).

Мелатонін здатний протистояти виснаженню $\beta$-клітин на ранніх етапах розвитку метаболічного синдрому, протидіє гіперсекреції інсуліну, знижує його до базального рівня. Це означає, що використання мелатоніну може зберегти повноцінну активність $\beta$-клітин у пацієнта після масового пошкодження токсичними агентами. На відміну від усіх інших гормонів для мелатоніну не виявлено негативного зворотного зв'язку, він позитивно діє як на клітини епіфіза, так і на інші клітини організму. Основний регулятор його секреції - характер освітленості. Таким чином, захисна дія мелатоніну за порушення вуглеводного обміну виявляється у формуванні циркадіанного періодизму шляхом модуляції експресії часових генів (Szosland, 2010).

У нормі інсулінозалежна активація фосфоінозитольного шляху супроводжується стимуляцією росту судин, збільшенням числа функціонуючих капілярів, інтенсифікацією кровотоку та транслокацією транспортного білка ГЛЮТ-4, що зумовлює швидке захоплення глюкози (Borodina et al., 2016). При MC або інсулінорезистентності цей сигнальний шлях блокується. Інший шлях інсулінозалежної активації пов'язаний із запуском позаклітинних кіназ ERK1/MAPK і ERK2/MAPK, які активують прозапальний процес, що викликає зростання та проліферацію гладеньком'язових клітин. МАР-кіназний шлях внаслідок секреції ендотеліну-1 спричинює звуження судин. Сам ендотелін-1 чутливий до поглинання глюкози тканиною скелетної мускулатури та індукує резистентність до глюкози периферичних тканин. За гіперінсулінемії розвиваються атеросклеротичні ушкодження внаслідок гіперстимуляції фосфоінозитольного шляху.

Перебіг як клінічного, так і експериментального діабету супроводжується залученням у патологічний процес генетичної компоненти. На $\beta$-клітинах підшлункової залози мишей із нокаутом гена MP1 порушується метаболізм глюкози та підвищується резистентність до інсуліну, що рівноцінно ЦД ІІ типу в людини (Jia et al., 2007). При цьому зростає синтез мелатоніну в шишкоподібній залозі та індукуються часові гени Per1 i Bmal1 (Hotamisligil et al., 1993).

Генезис пінеалектоміє-індукованої резистентності до інсуліну та зниження толерантності до глюкози в клітинах пов'язані 3 наслідками відсутності мелатоніну, що викликає розвиток порушень в інсуліновому сигнальному шляху та зниження експресії генів GLUT4 і вмісту білка. Інсулін-чутливі тканини (біла та бура жирові тканини, скелетні та серцевий м'язи) за пінеалектомії характеризуються суттєвішим зниженням мРНК GLUT4, вмістом мікросомальних і мембранних білків, які компенсуються під час проведення терапії мелатоніном (Hotamisligil et al., 1993; Erikstrup et al., 2006; McCarthy, 2010). Існуе функціональний синергізм між мелатоніном та інсуліном. Мелатонін здатний через мембранні рецептори МТ1 викликати швидке тирозин-фосфорилювання й активувати тирозинкіназу бета-субодиниці рецептора інсуліну та мобілізацію декількох внутрішньоклітинних етапів трансдукції інсулін-сигнального шляху (фосфорилювання тирозину IRS-1, IRS-1/PI(3)-kinase i IRS-1/SHP-2 асоціації, а також серин, МАР-кінази та STAT3 фосфорилювання) (Yang et al., 2005; Graham et al., 2006).

SRBP-4 - білок із родини ліпокаліну, який зв'язує та транспортує ретинол у сироватці крові, беспосередньо пов'язаний із вісцеральним ожирінням і резистентністю до інсуліну. SRBP-4 секретується, в основному, у печінці та адипоцитах (Aeberli et al., 2007; Wolf, 2007). У печінці цей білок, зв'язаний iз транстиретином, концентрація якого зменшується за гострої інфекції та стресу. У дослідах на мишах показано, що SRBP-4, який вивільнився 3 адипоцитів, викликає резистентність до інсуліну в печінці та скелетних м'язах (Wolf, 2007).

Доведено (Graham et al., 2006) асоціацію між SRBP-4 i ожирінням, зокрема, вісцерального типу (Yang et al., 2005), a також резистентність до інсуліну та розвиток діабету типу II (Janke et al., 2006; Takashima et al., 2006). У дорослих японців із порушенням толерантності до глюкози, концентрація SRBP-4 не корелювала 3 індексом маси тіла, але корелювала 3 підвищеними концентраціями тригліцеридів (Knutson et al., 2007; Srivastava and Krishna, 2010). Отже, концентрація SRBP-4 тісніше пов'язана з аномальними рівнями ліпідів при ожирінні, а не тільки ожирінням як нозологічним захворюванням (Erikstrup et al., 2006). Іншими дослідниками доведено зв'язок між концентрацією SRBP-4 та поширеністю ожиріння та метаболічного синдрому, незалежно від концентрації сироваткового ретинолу (Zheng et al., 1999; Yang et al., 2005).

\section{Депривація сну та ожиріння}

Жирова тканина синтезує речовини, що впливають на вуглеводний обмін, зокрема адипокіни, адипонектин, лептин, адипсин, вісфатин, апелін, васпін. Вони володіють чутливістю до інсуліну, мають антиатеросклеротичний і протизапальний ефекти (Arita et al., 1999; Ouchi et al., 1999). Ці речовини несуть інформацію від жирової тканини до інсуліночутливих тканин про запас поживних речовин в організмі.

Більшість гормонів, що регулюють апетит, також мають циркадіанний ритм секреції, пов'язаний із циклом «сон неспання». Лептин «інформує» клітини організму про стан жирового обміну та масу тіла. Впливаючи на гіпоталамус, він пригнічує апетит. У фізіологічних концентраціях лептин гальмує секрецію інсуліну, а у великих концентраціях - тромбоз та інсулінорезистентність. Використання лептину зменшує масу тіла (Palou-Oliver et al., 2006), постійно підвищений рівень лептину та резистину в крові може призвести до розвитку кардіоміопатії (Bobbert et al., 2012).

Адипонектин зменшує окиснювальний стрес, запалення, тромбоутворення, але ініціює інсулінорезистентність і пошкодження судин (Lee et al., 2011). Зниження рівня адипонектину в крові виявлено в людей 3 ожирінням й у пацієнтів із симптомами ЦД II типу (Hotta et al., 2000). Вважають, що адипонектин протидіє розвитку метаболічного синдрому (МС) (Cui et al., 2011). Очевидно, що вісфатин, апелін, васпін жирової тканини відіграють провідну роль в атеросклеротичних пошкодженнях при ожирінні (Palios et al., 2012).

Лептин і грелін мають протилежний вплив на центри голоду та насичення в гіпоталамусі, через взаємодію з нейропептидами, що контролюють споживання їжі (нейропептид Y, агутиподібний білок, меланокортин тощо), Відповідаючи, таким чином, за регуляцію маси тіла, лептин впливає на запаси жиру в організмі через центральні механізми, його рівні збільшуються після їжі та в нічний час, що зумовлює зниження апетиту. Грелін продукується, в основному, P/D1-клітинами слизової оболонки фундального відділу шлунка, стимулює апетит і циркулює в неактивній формі, стає біологічно активним у відповідь на голодування. Під час сну відбувається підвищення загального греліну зі зменшенням співвідношення 
загальний / активний грелін порівняно з неспанням. За вимушеного зміщення добового ритму в дорослих спостерігається зниження концентрації лептину, підвищення постпрандіальної глікеміі, інсуліну, середнього артеріального тиску та зміна ритму секреції кортизолу з вищими піками перед сном і після пробудження (Scheer et al., 2009).

Люди, які працюють за змінним графіком, мають вищу захворюваність на цукровий діабет, ожиріння та серцево-судинну патологію (Bass and Takahashi, 2010). Також доказаний зв'язок між зміною експресії clock-генів і цукровим діабетом (Woon et al., 2007), ожирінням і метаболічним синдромом (Scott et al., 2008), хоча патогенетичні механізми, що лежать в основі цих асоціацій, до кінця не вивчені.

У багатьох країнах світу дедалі гострішою стає проблема порушень сну, яка часто супроводжується ростом захворюваності на ожиріння. Прогрес у соціально-економічному розвитку, поява штучного освітлення на початку минулого століття, загальна комп'ютеризація, телебачення та інші електронні засоби масової інформації викликали зміни способу життя людей і скорочення тривалості сну.

У промислово розвинених країнах упродовж останніх десятиліть середній час сну зменшився. Якщо в 1960 році його добова тривалість у середньому була вісім-дев'ять годин, то в 1995 році вона скоротилася до семи годин. Нині майже третина дорослого населення планети спить менше шести годин на добу. Епідеміологічними дослідженнями показано, що зниження тривалості сну спричиняє підвищення індексу маси тіла, і в кінцевому результаті викликає ожиріння (Hasler et al., 2004). Робота в нічні зміни часто супроводжується порушенням нормального добового режиму сну та зниженням його якості (Boivin et al., 2007), i $є$ одним із чинників розвитку ожиріння, ЩД II типу та метаболічного синдрому (Karlsson et al., 2001; Szosland, 2010).

Причинний зв'язок між порушенням сну та метаболічними зрушеннями доведено низкою лабораторних досліджень (Knutson et al., 2008; Van Cauter and Knutson, 2008). У разі зменшення тривалості сну спостерігається підвищений апетит, зростають рівні лептину та греліну в крові та знижується толерантність до глюкози, що теж сприяє розвитку ожиріння (Knutson and Knutson, 2008). Цікаво зазначити, що рівні у крові адипокінових гормонів корелюють із тривалістю сну (Mühlbauer et al., 2009) та спричиняють накопичення білого жиру (Barclay et al., 2012). Отже, втрата сну або погана його якість можуть викликати дисліпідемію та підвищене накопичення жиру в черевній порожнині людей (Karlsson et al., 2001; SalgadoDelgado et al., 2010; Dallman et al., 2012).

У період з 1960 по 2000 рік середня тривалість нічного сну скоротилася на 1,5-2,0 години (Hiestand et al., 2006). За даними зарубіжних джерел, 35\% дорослого населення сплять менше семи годин на добу, а одна четверта частина дорослого та велика частина дітей і підлітків має проблеми зі сном. На сучасному етапі не існує жодного об'єктивного методу для визначення тривалості сну, достатнього для дорослих. Проте тривалість сну, в середньому, 7,5 години на добу вважається оптимальною для дорослого, за відсутності сонливості в денний час (Grandner et al., 2010; Centers for Disease Control and Prevention, 2011). За даними метааналізу вивчення тривалості сну, можна дійти висновку про підвищений ризик розвитку ожиріння в осіб із недостатньою тривалістю сну як серед дорослих, так i серед дітей. Скорочення тривалості сну на одну годину асоційоване зі збільшенням індексу маси тіла (IMT) на 0,35 кг/ м $^{2}$ (Cappuccio et al., 2008).

За даними дослідження the Whitehall II Study, існують достовірні асоціації між короткою тривалістю сну (5 год), індексом маси тіла, окружністю талії, а також підвищеним ризиком розвитку ожиріння (St-Onge et al., 2011). Підтверджено гіпотезу про те, що скорочення сну спричинює збільшення маси тіла 3 плином часу (Hasler et al., 2004; Gunderson et al., 2008).

Оскільки більшість епідеміологічних досліджень підтвердили наявність асоціацій між скороченням тривалості сну та надмірною масою тіла, наразі триває інтенсивне вивчення кореляційних зв'язків між сном і ожирінням. Усе більше накопичується даних, які підтверджують те, що скорочення та погіршання якості сну можуть викликати порушення метаболізму, в тому числі жирового обміну.

Яскраві приклади поєднання ендокринно-обмінних, мотиваційних порушень і порушень сну - синдром нічного відчуття голоду, а також сезонні афективні розлади. Харчова поведінка в пацієнтів із синдромом нічного відчуття голоду представлена переїданням із порушенням добового ритму прийому їжі, що в клініці проявляється тріадою симптомів: ранкова анорексія, вечірня або нічна булімія та гіперсомнія (підвищена денна сонливість, збільшення тривалості нічного сну за відсутності «освіжаючого» ефекту сну). Відчуття насичення при цьому синдромі виникає дуже повільно, при цьому хворі не можуть заснути, не з'ївши великої кількості їжі, а фізична активність у цих пацієнтів мінімальна упродовж усього дня. Порушення сну та харчової поведінки можуть спостерігатися в межах сезонних афективних розладів (САР), головний клінічний симптом яких депресія, яка виникає винятково в «темну» пору року, що поєднується з булімією та гіперсомнією. У світлий період року в пацієнтів із САР не виявляється ніяких порушень, крім ожиріння (Voznesenskaja, 2009).

Депривація сну - порушення або повна відсутність задоволення потреби уві сні. Це може виникнути як результат розладів сну, усвідомленого вибору або примусово, наприклад в експерименті. Показано зниження нічної та підвищення денної концентрації греліну в дослідженнях з обмеженням часу сну у здорових добровольців, що сприяє підвищенню апетиту, гіперфагії, збільшуючи ризик розвитку ожиріння в майбутньому (Spiegel et al., 2004). Ці дані узгоджуються з дослідженням Таheri et al. (2004), які виявили зниження концентрації лептину, підвищення греліну в пацієнтів із недостатнім сном.

Значущу роль у підтриманні енергетичного балансу відіграють тиреоїдні гормони, які підвищують температуру тіла та рівень основного обміну, посилюють ліполіз і гальмують ліпогенез. Також повідомляється, що втрата сну впливає на функцію гіпоталамо-гіпофізарно-тиреоїдної осі. Гостра депривація сну пов'язана 3 підвищенням ТТГ, а також рівнем зв'язаного $\mathrm{T}_{3} \mathrm{i}$ зв'язаного $\mathrm{T}_{4}$ у вечірні години (Gary et al., 1996). Kessler et al. (2010) показали, що часткове обмеження часу сну (до 5,5 годин упродовж 14 діб) у здорових пацієнтів середнього віку супроводжувалося помірним, але статистично значущим зниженням рівня ТТГ і вільного $\mathrm{T}_{4}$ у жінок у ранкові години. Ці результати дозволяють припустити наявність зв'язків між метаболічними та психічними змінами в пацієнтів із порушеннями сну з тиреоїдною функцією, що вимагають подальшого вивчення.

Низка праць продемонструвала зв'язок між гострою втратою сну та порушенням імпульсної та нічної секреції соматотропного гормону, що вважається важливим ліполітичним чинником (Weibel et al., 1997).

Експерименти, в яких вивчено вплив тривалості сну на енергетичний обмін, нечисленні. Jonge et al. (2012) оцінюючи основний обмін, установили, що скорочення часу сну та низька його ефективність асоційовані з підвищенням витрати енергії, вільного кортизолу та дофаміну в сечі, а низька ефективність сну - 3 підвищенням дихального коефіцієнта. Таким чином, високий дихальний коефіцієнт - чинник, який спричинює накопичення жирової маси.

Зміни режиму харчування у поєднанні з дизритмією добового прийому їжі переважають у пацієнтів з ожирінням. За умов десинхронозу виникають розлади, які спричиняють розвиток метаболічного синдрому (Rapoport et al., 2013).

\section{Висновок}

Десинхроноз - одна з причин ожиріння, наслідок дизрегуляторних зрушень у хроноперіодичній системі - між супрахіазматичними ядрами гіпоталамуса та секреторною активністю шишкоподібної залози. 


\section{References}

Aeberli, I., Biebinger, R., Lehmann, R., L'allemand, D., Spinas, G. A., \& Zimmermann, M. B. (2007). Serum retinol-binding protein 4 concentration and its ratio to serum retinol are associated with obesity and metabolic syndrome components in children. The Journal of Clinical Endocrinology and Metabolism, 92(11), 4359-4365.

Akmali, M., Ahmadi, R., \& Vessal, M. (2010). Pre- and post-treatment of streptozocin administered rats with melatonin: Effects on some hepatic enzymes of carbohydrate metabolism. Archives of Iranian Medicine, 13(2), 105-110.

Antunes, L. C., Levandovski, R., Dantas, G., Caumo, W., \& Hidalgo, M. P. (2010). Obesity and shift work: Chronobiological aspects. Nutrition Research Reviews, 23(1), 155-168.

Arita, Y., Kihara, S., Ouchi, N., Takahashi, M., Maeda, K., \& Miyagawa, J. (1999). Paradoxical decrease of an adipose specific protein, adiponectin, in obesity. Biochemical and Biophysical Research Communications, 257(1), 79-83.

Bahr, I., Muhlbauer, E., Schulte, H., \& Peschke, E. (2011). Melatonin stimulates glucagon secretion in vitro and in vivo. Journal of Pineal Research, 50, 336-344.

Balagopal, P., Graham, T. E., Kahn, B. B., Altomare, A., Funanage, V., \& George, D. (2007). Reduction of elevated serum retinol binding protein in obese children by lifestyle intervention: Association with subclinical inflammation. The Journal of Clinical Endocrinology and Metabolism, 92(5), 1971-1974.

Baranov, V. S., Baranova, E. V., Ivaschenko, T. E., \& Aseev, M. V. (2000). Genom cheloveka i genyi predraspolozhennosti: Vvedenie v prediktivnuyu meditsinu [The human genome and susceptibility genes: An introduction to predictive medicine]. Inter-Medika, Saint Petersburg (in Russian).

Barclay, J. L., Husse, J., Bode, B., Naujokat, N., Meyer-Kovac, J., Schmid, S. M., Lehnert, H., \& Oster, H. (2012). Circadian desynchrony promotes metabolic distuption in a mouse model of shiftwork. PLoS ONE, 7(5), e37150.

Bass, J., \& Takahashi, J. S. (2010). Circadian integration of metabolism and energetics. Science, 330(6009), 1349-1354.

Bespjatyh, A. J., Brodskij, V. J., Burlakova, O. V., Golichenkov, V. A., Voznesenskaja, L. A., Kolesnikov, D. B., Molchanov, A. J., \& Rapoport, S. I. (2009). Melatonin: Teorija i praktika [Melatonin: Theory and Practice]. MedpraktikaM, Moscow (in Russian).

Biggi, N., Consonni, D., Galluzzo, V., Sogliani, M., \& Costa, G. (2008). Metabolic syndrome in permanent night workers. Chronobiology International, 25(2), 443-454.

Bobbert, P., Jenke, A., Bobbert, T., Kuhl, U., Lassner, D., \& Scheibenbogen, C. (2012). High leptin and resisten expression in chronic heart failure: Adverse outcome in patients with dilated and inflammatory cardiomyopathy. European Journal of Heart Failure, 14(11), 1265-1275.

Boivin, D. B., Tremblay, G. M., \& James, F. O. (2007). Working on atypical schedules. Sleep Medicine, 8(6), 578-589.

Borodina, C. B., Gapparova, K. M., Zajnudinov, Z. M., \& Grigor'jan, O. N. (2016). Geneticheskie prediktory razvitija ozhirenija [Genetic predictors of obesity]. Ozhirenie i Metabolizm, 13(2), 7-13 (in Russian).

Brondel, L., Romer, M. A., Nougues, P. M. Touyarou, P., \& Davenne, D. (2010). Acute partial sleep deprivation increases food intake in healthy men. The American Journal of Clinical Nutrition, 91(6), 1550-1559.

Broussard, J., \& Brady, M. J. (2010). The impact of sleep disturbances on adipocyte function and lipid metabolism. Best Practice and Research: Clinical Endocrinology and Metabolism, 24(5), 763-773.

Cappuccio, F. P., Taggart, F. M., Kandala, N. B., Currie, A., Peile, E., Stranges, S., \& Miller, M. A. (2008). Meta-analysis of short sleep duration and obesity in children and adults. Sleep, 31(5), 619-626.

Carlos, F., Silva-Nunes, C. J., Flores, O., Brito, M., Doria, G., Veiga, L., \& Baptista, P. V. (2013). Association of FTO and PPARG polymorphisms with obesity in Portuguese women. Diabetes, Metabolic Syndrome and Obesity, 6, 241-245.

Cejkova, P., Novota, P., Cerna, M. Kolostova, K., Novakova, D., Kucera, P., Novak, J., Andel, M., Weber, P., \& Zdárský, E. (2007). KCNJ11 E23K polymorphism and diabetes mellitus with adult onset in Czech patients. Folia Biologica (Praha), 53(5), 173-175.

Cui, J., Panse, S., \& Falkner, B. (2011). The role of adinopectin in metabolic and vascular disease: A review. Clinical Nephrology, 75(1), 26-33.

Dalgaard, L. T. (2011). Genetic variance in uncoupling protein 2 in relation to obesity, type 2 diabetes, and related metabolic traits: Focus on the functional 866G $>$ A promoter variant (rs659366). Journal of Obesity, 2011,340241.

Dallmann, R., Viola, A. U., Tarokh, L., Cajochen, C., \& Brown, S. A. (2012). The human circadian metabolome. Proceedings of the National Academy of Sciences, 109(7), 2625-2629.

De Luis, D., Gonzalez Sagrado, M., Aller, R., Izaola, O., \& Conde, R. (2007). Influence of the Trp64Arg polymorphism in the beta 3 adrenoreceptor gene on insulin resistance, adipocytokine response, and weight loss secondary to lifestyle modification in obese patients. European Journal of Internal Medicine, 18(8), 587-592.
Donga, E., van Dijk, M., van Dijk, J. G., Biermasz, N. R., Lammers, G. J., van Kralingen, K. W., Corssmit, E. P., \& Romijn, J. A. (2010). A single night of partial sleep deprivation induces insulin resistance in multiple metabolic pathways in healthy subjects. The Journal of Clinical Endocrinology and Metabolism, 95(6), 2963-2968.

Erikstrup, C., Mortensen, O. H., \& Pedersen, B. K. (2006). Retinol-binding protein 4 and insulin resistance. The New England Journal of Medicine, 355(13), 1393-1394.

Everson, C. A., Crowley, W. R. (2004). Reductions in circulating anabolic hormones induced by sustained sleep deprivation in rats. American Journal of Physiology, Endocrinology and Metabolism, 286(6), 1060-1070.

Gary, K. A., Winokur, A., Douglas, S. D., Kapoor, S., Zaugg, L., \& Dinges, D. F. (1996). Total sleep deprivation and the thyroid axis: Effects of sleep and waking activity. Aviation Space and Environmental Medicine, 67(6), 513-519.

Gonen, M. S., Arikoglu, H., Erkoc Kaya, D., Ozdemir, H., Ipekci, S. H., Arslan, A., Kayis, S. A., \& Gogebakan, B. (2012). Effects of single nucleotide polymorphisms in K(ATP) channel genes on type 2 diabetes in a Turkish population. Archives of Medical Research, 43(4), 317-323.

Graham, T. E., Yang, Q., Blüher, M., Hammarstedt, A., Ciaraldi, T. P., Henry, R. R, Wason, C. J., Oberbach, A., Jansson, P. A., Smith, U., \& Kahn, B. B. (2006). Retinol-binding protein 4 and insulin resistance in lean, obese, and diabetic subjects. New England Journal of Medicine, 354(24), 2552-2563.

Grandner, M. A., Hale, L., Moore, M., \& Patel, N. P. (2010). Mortality associated with short sleep duration: the evidence, the possible mechanisms, and the future. Sleep Medicine Reviews, 14(3), 191-203.

Gunderson, E. P., Rifas-Shiman, S. L., Oken, E., Rich-Edwards, J. W., Kleinman, K. P., Taveras, E. M., \& Gillman, M. W. (2008). Association of fewer hours of sleep at 6 months postpartum with substantial weight retention at 1 year postpartum. American Journal of Epidemiology, 167(2), 178-187.

Guzik, T. J., Mangalat, D., \& Korbut, R. (2006). Adipocytokines - novel link between inflammation and vascular function? Journal of Physiology and Pharmacology, 57(4), 505-528.

Ha, E., Yim, S. V., Chung, J. H., Yoon, K. S., Kang, I., Cho, Y. H., \& Baik, H. H. (2006). Melatonin stimulates glucose transport via insulin receptor substrate-1/phosphatidylinositol 3-kinase pathway in $\mathrm{C}_{2} \mathrm{C}_{12}$ murine skeletal muscle cells. Journal of Pineal Research, 41(1), 67-72.

Hairston, K. G., Bryer-Ash, M., Norris, J. M., Haffner, S., Bowden, D. W., $\&$ Wagenknecht, L. E. (2010). Sleep duration and five-year abdominal fat accumulation in a minority cohort: The IRAS family study. Sleep, 33(3), 289-295.

Hasler, G., Buysse, D. J., Klaghofer, R., Gamma, A., Ajdacic, V., Eich, D., Rössler, W., \& Angst, J. (2004). The association between short sleep duration and obesity in young adults: A 13-year prospective study. Sleep, 27(4), 661-666.

Hayes, A. L., Xu, F., Babineau, D., \& Patel, S. R. (2011). Sleep duration and circulating adipokine levels. Sleep, 34(2), 147-152.

Hiestand, D., Britz, P., Goldman, M., \& Phillips B. (2006). Prevalence of symptoms and risk of sleep apnea in the US population. Results from the National Sleep Foundation Sleep in America 2005 poll. Chest, 130, 780-786.

Hotamisligil, G. S., Shargill, N. S., \& Spiegelman, B. M. (1993). Adipose expression of tumor necrosis factor-alpha: Direct role in obesity-linked insulin resistance. Science, 259(5091), 87-91.

Hotta, K., Funahashi, T., Arita, Y., Takahashi, M., Matsuda, M., \& Okamoto, Y. (2000). Plasma concentrations of a novel adipose-specific protein adiponectin in type 2 diabetic patients. Arteriosclerosis, Thombosis and Vascular Biology, 20(6), 1595-1599.

Janke, J., Engeli, S., Boschmann, M., Adams, F., Böhnke, J., Luft, F. C. Sharma, A. M., \& Jordan, J. (2006). Retinol-binding protein 4 in human obesity. Diabetes, 55(10), 2805-2810

Jia, W., Wu, H., Bao, Y. Wang, C., Lu, J., Zhu, J., \& Xiang, K. (2007). Association of serum retinol-binding protein 4 and visceral adiposity in Chinese subjects with and without type 2 diabetes. Journal of Clinical Endocrinology and Metabolism, 92(8), 3224-3229.

Jonge, L., Zhao, X, Mattingly, M. S., Zuber, S. M., Piagoi, P. Csako, G., \& Cizza, G. (2012). Poor sleep quality and sleep apnea are associated with higher resting energy expenditure in obese individuals with short sleep duration. Journal of Clinical Endocrinology and Metabolism, 97(8), 2881-2889.

Karlsson, B., Knutsson, A., \& Lindahl, B. (2001). Is there an association between shift work and having a metabolic syndrome? Results from a population based study of 27,485 people. Occupational and Environmental Medicine, 58(11), 747-752.

Kasradze, D., Tavartkiladze, A., Kasradze, M., \& Nozadze, P. (2010). The study of melatonin protective activity on pancreatic beta-cells under the condition of alloxan-induced diabetes during aging. Georgian Medical News, $189,56-63$.

Kessler, L., Nedeltcheva, A., Imperial, J., \& Penev, P. D. (2010). Changes in Serum TSH and Free T4 during Human Sleep Restriction. Sleep, 33(8), 1115-1118. 
Klimov, A. N., \& Nikulcheva, N. G. (1999). Obmen lipidov i lipoproteidov i ego narusheniya [Exchange of lipids and lipoproteins and its disorders] Piter Kom, Saint Petersburg (in Russian).

Knutson, K. L., \& Van Cauter, E. (2008). Associations between sleep loss and increased risk of obesity and diabetes. Annals of the New York Academy of Sciences, 1129, 287-304.

Knutson, K. L., Spiegel, K., Penev, P., \& Van Cauter, E. (2007). The metabolic consequences of sleep deprivation. Sleep Medicine Reviews, 11(3), 163-178.

Koo, B. K., Cho, Y. M., Park, B. L., Cheong, H. S., Shin, H. D., Jang, H. C., Kim, S. Y., Lee, H. K., \& Park, K. S. (2007). Polymorphisms of KCNJ11 (Kir6.2 gene) are associated with Type 2 diabetes and hypertension in the Korean population. Diabetic Medicine, 24, 178-186.

Kovac, J., Husse, J., \& Oster, H. (2009). A time to fast, a time to feast: The crosstalk between metabolism and the circadian clock. Molecules and Cells, 28(2), 75-80.

Laposky, A. D., Bass, J., Kohsaka, A., \& Turek, F. W. (2008). Sleep and circadian rhythms: Key components in the regulation of energy metabolism. FEBS Letters, 582(1), 142-151.

Lee, E. B., Warmann, G., Dhir, R., \& Ahima, R. S. (2011). Metabolic dysfunction associated with adiponectin deficiency enhances kainic-acidinduced seizure severity. Journal of Neuroscience, 31(40), 14361-14366.

Lin, G. J., Huang, S. H., Hueng, D. J., Chen, Y. W., Chien, M. W., Chia, W. T., Chang, D. M., \& Sytwu, H. K. (2009). Melatonin prolongs islet graft survival in diabetic NOD mice. Journal of Pineal Research, 47, 284-292.

Lundina, G. V., Mehrjakov, S. A., \& Tot'mjanina, E. V. (2014). Narushenija cirkadiannyh ritmov u detej s ozhireniem [Disturbances of circadian rhythms in children with obesity]. Uchenye Zapiski Orlovskogo Gosudarstvennogo Universiteta, 63, 46-47 (in Russian).

McCarthy, M. I. (2010). Genomics, type 2 diabetes, and obesity. The New England Journal of Medicine, 363(24), 2339-2350.

Mitchell, J. A., Church, T. S., Rankinen, T., Earnest, C. P., Sui, X., \& Blair, S. N. (2010). FTO genotype and the weight loss benefits of moderate intensity exercise. Obesity, 18(3), 641-643.

Molchanov, A. J. (2012). Molekuljarnaja genetika i biohimija melatonina [Molecular genetics and biochemistry of melatonin]. In: Melatonin: perspektivy primenenija v klinike. IMA-PReSS, Moscow (in Russian).

Mühlbauer, E., Gross, E., Labucay, K., Wolgast, S., \& Peschke, E. (2009). Loss of melatonin signalling and its impact on circadian rhythms in mouse organs regulating blood glucose. European Journal of Pharmacology, 606, 61-71.

Mulder, H., Nagorny, C. L., Lyssenko, V., \& Groop, L. (2009). Melatonin receptors in pancreatic islets: Good morning to a novel type 2 diabetes gene. Diabetologia, 52(7), 1240-1249.

Nishida, S. (2005). Metabolic effects of melatonin on oxidative stress and diabetes mellitus. Endocrine, 27(2), 131-136.

Ouchi, N., Kihara, S., Arita, Y., Maeda, K., Kuriyama, H., Okamoto, Y., Hotta, K., Nishida, M., Takahashi, M., Nakamura, T., Yamashita, S., Funahashi, T., \& Matsuzawa, Y. (1999). Novel modulator for endothelial adhesion molecules: Adipocytederived plasma adiponectin. Circulation, 100(25), 2473-2476.

Palios, J., Kadoglou, N. P. E., \& Lampropoulos, S. (2012). The pathophysiology of HIV/HAART-related metabolic syndrome leading to cardiovascu cardiovascular disorders: The emerging role of adipokines. Experimental Diabetes Research, 2012, 103063.

Palou-Oliver, A., Piko-Pou, K., Oliver-Vara, P., Sanches Roig, H., \& Miral'esBorrachina, O. (2006). Primenenie leptina dlja predotvrashhenija izbytochnoj massy tela i kompozicii, soderzhashhie leptin [Use of leptin for the prevention of overweight and compositions containing leptin]. Patent RF N2450825 (in Russian).

Peschke, E. (2008). Melatonin, endocrine panreas and diabetes. Journal of Pineal Research, 44(1), 26-40.

Peschke, E., Wolgast, S., Bazwinsky, I., Pönicke, K., \& Muhlbauer, E. (2008). Increased melatonin synthesis in pineal glands of rats in streptozotocin induced type 1 diabetes. Journal of Pineal Research, 45(4), 439-448.

Picchi, A., Gao, X., Belmadani, S., Potter, B. J., Focardi, M., Chilian, W. M., \& Zhang, C. (2006). Tumor necrosis factor-alpha induces endothelial dysfunction in the prediabetic metabolic syndrome. Circulation Research, 99(1), 69-77.

Picinato, M. C., Hirata, A. E., Cipolla-Neto, J., Curi, R., Carvalho, C. R., Anhe, G. F., \& Carpinelli, A. R. (2008). Activation of insulin and IGF-1 signaling pathways by melatonin through MT1 receptor in isolated rat pancreatic islets. Journal of Pineal Research, 44(1), 88-94.

Qian, L., Xu, K., Xu, X., Gu, R., Liu, X., Shan, S., \& Yang, T. (2013). UCP2866G/A, Ala55Val and UCP3-55C/T polymorphisms in association with obesity susceptibility - a meta-analysis study. PLoS One, 8(4), e58939.

Qiu, L., Na, R., Xu, R., Wang, S., Sheng, H., Wu, W., \& Qu, Y. (2014). Quantitative assessment of the effect of KCNJ11 gene polymorphism on the risk of type 2 diabetes. PLoS One, 9(4), e93961.

Rapoport, S. I., Molchanov, A. Y., Golichenkov, V. A., Burlakova, O. V., Suprunenko, E. A., \& Savchenko, E. S. (2013). Metabolicheskiy sindrom i melatonin [Metabolic syndrome and melatonin]. Klinicheskaya Meditsina, 11, 8-14 (in Russian).
Reiter, R. J. (1980). The pineal gland and int hormones in the control of reproduction in mammals. Endocrine Reviews, 1(2), 109-131.

Ríos-Lugo, M. J., Cano, P., Jiménez-Ortega, V., Fernández-Mateos, M. P., Scacchi, P. A., Cardinali, D. P., \& Esquifino, A. I. (2010). Melatonin effect on plasma adiponectin, leptin, insulin, glucose, triglycerides and cholesterol in normal and hight fat-fed rats. Journal of Pineal Research, 49(4), 342-348.

Rosa, J. C., Lira, F. S., Venancio, D. P., Cunha, C. A., Oyama, L. M., Pimentel, G. D., Tufik, S., Oller do Nascimento, C. M., Santos, R. V., \& de Mello, M. T. (2010). Sleep deprivation affects inflammatory marker expression in adipose tissue. Lipids in Health Disease, 9, 125.

Sakamoto, Y., Inoue, H., Keshavarz, P., Miyawaki, K., Yamaguchi, Y., Moritani, M., Kunika, K., Nakamura, N., Yoshikawa, T., Yasui, N., Shiota, H., Tanahashi, T., \& Itakura, M. (2007). SNPs in the KCNJ11-ABCC8 gene locus are associated with type 2 diabetes and blood pressure levels in the Japanese population. Journal of Human Genetics, 52(10), 781-793.

Salgado-Delgado, R., Angeles-Castellanos, M., Saderi, N., Buijs, R. M., \& Escobar, C. (2010). Food intake during the normal activity phase prevents obesity and circadian desynchrony in a rat model of night work Endocrinology, 151(3), 1019-1029.

Scheer, F. A., Hilton, M. F., Mantzoros, C. S., \& Shea, S. A. (2009). Adverse metabolic and cardiovascular consequences of circadian misalignment. Proceedings of the National Academy of Sciences, 106(11), 4453-4458.

Scott, E. M., Carter, A. M., \& Grant, P. J. (2008). Association between polymorphisms in the Clock gene, obesity and the metabolic syndrome in man. International Journal of Obesity, 32(4), 658-662.

Shieh, J. M., Wu, H. T., Cheng, K. C., \& Cheng, J. T. (2009). Melatonin ameliorates high fat diet-induced diabetes and stimulates glycogen synthesis via a PKCzeta-Akt-Gsk3-beta pathway in hepatic cells. Journal of Pineal Research, 47(4), 339-344.

Spiegel, K., Tasali, E., Penev, P., \& Cauter, E. V. (2004). Brief communication: Sleep curtailment in healthy young men is associated with decreased leptin levels, elevated ghrelin levels, and increased hunger and appetite. Annals of Internal Medicine, 141(11), 846-850.

Srinivasan, V., Ohta, Y., Espino, J., Pariente, J., Rodríguez, A., Mohamed, M., \& Zakaria, R. (2013). Metabolic syndrome, its pathophysiology and the role of melatonin metabolic. Recent Patents on Endocrine, Metabolic and Immune Drug Discovovery, 7(1), 11-25.

Srivastava, R. K., \& Krishna, A. (2010). Melatonin modulates glucose homeostasis during winter dormancy in a vespertilionid bat, Scotophilus heathi. Comparative Biochemistry and Physiology Part A. Molecular and Integrative Physiology, 155(3), 392-400.

St-Onge, M. P., Roberts, A. L., Chen, J., Kelleman, M., O'Keeffe, M., RoyChoudhury, A., \& Jones, P. J. (2011). Short sleep duration increases energy intakes but does not change energy expenditure in normal-weight individuals. The American Journal of Clinical Nutrition, 94(2), 410-416.

Syromjatnikova, L. I., Spigina, T. A., \& Shestakov, V. V. (2010). Cirkadiannyj ritm i depressija u kardiologicheskih pacientov. Psihicheskie Rasstrojstva v Obshhej Medicine, 1, 19-23 (in Russian).

Szosland, D. (2010). Shift work and metabolic syndrome, diabetes mellitus and ischaemic heart disease. International Journal of Occupational Medicine and Environmental Health, 23(3), 287-291.

Taheri, S., Lin, L., Austin, D., Young, T., \& Mignot, E. (2004). Short sleep duration is associated with reduced leptin, elevated ghrelin, and increased body mass index. PLoS Medicine, 1(3), e62.

Takashima, N., Tomoike, H., \& Iwai, N. (2006). Retinol-binding protein 4 and insulin resistance. The New England Journal of Medicine, 355(13), 1392.

Van Cauter, E., \& Knutson, K. L. (2008). Sleep and the epidemic of obesity in children and adults. European Journal of Endocrinology, 159(Suppl 1), 59-66.

Voznesenskaja, T. G. (2009). Rasstrojstva pishhevogo povedenija pri ozhirenii $\mathrm{i}$ ih korrekcija [Eating disorders in obesity and their correction]. Farmateka, 12, 91-94 (in Russian).

Weibel, L., Follenius, M., Spiegel, K., Gronfier, C., \& Brandenberger, G. (1997). Growth hormone secretion in night workers. Chronobiology International, 14(1), 49-60.

Wolf, G. (2007). Serum retinol-binding protein: A link between obesity, insulin resistance, and type 2 diabetes. Nutrition Reviews, 65(5), 251-256.

Woon, P. Y., Kaisaki, P. J., Bragança, J., Bihoreau, M. T., Levy, J. C., Farrall, M., \& Gauguier, D. (2007). Aryl hydrocarbon receptor nuclear translocator-like (BMAL1) is associated with susceptibility to hypertension and type 2 diabetes. Procedings of the National Academy of Sciences, 104(36), 14412-14417.

Yang, Q., Graham, T. E., Mody, N., Preitner, F., Peroni, O. D., Zabolotny, J. M., Kotani, K., Quadro, L., \& Kahn, B. B. (2005). Serum retinol binding protein 4 contributes to insulin resistance in obesity and type 2 diabetes. Nature, 436(7049), 356-362.

Zheng, B., Larkin, D. W., Albrecht, U., Sun, Z. S., Sage, M., Eichele, G., Lee, C. C., \& Bradley, A. (1999). The mPer2 gene encodes a functional component of the mammalian circadian clock. Nature, 400(6740), 169-173. 